\title{
OPEM
}

www.opem.org

Oriental Pharmacy and Experimental Medicine 2008 8(4), 400-407

DOI 10.3742/OPEM.2008.8.4.400

\section{Anti-inflammatory and Antimicrobial activities of Petroleum ether and Ethanol extracts of Scutia myrtina (Rhamnaceae)}

\author{
N Kritheka, R Sambath Kumar*, S Suresh Kumar, N Venkateswara Murthy, R Shanmuga Sundram, \\ P Perumal
}

Department of Pharmaceutics and Pharmaceutical Chemistry, Natural Product Research Laboratory, J.K.K. Nataraja College of Pharmacy, Komarapalayam 638 183, Namakkal, Tamilnadu, India

Received for publication November 07, 2007; accepted May 15, 2008

\begin{abstract}
SUMMARY
The aim of the present study is to investigate the anti-inflammatory and antimicrobial activity of petroleum ether and ethanol extracts of Scutia myrtina (Family: Rhamnaceae). In antiinflammatory activity carrageenan and histamine induced paw oedema and cotton pellet induced granuloma for acute and chronic inflammatory models were studied in Wister albino rats. Based on the results of the present study it can be concluded that petroleum ether and ethanol extract of Scutia myrtina at $400 \mathrm{mg} / \mathrm{kg}$ has potential anti-inflammatory effect and they act in a dose dependent manner. Both extracts of Scutia myrtina showed antimicrobial activity against all bacterial and fungal strains tested at the concentration of $100 \mu \mathrm{g} / \mathrm{ml}$. From the result, it can be concluded that the Scutia myrtina contain antibacterial and antifungal principle. Further more, besides the confirmation of the popular use; the obtained results demonstrate this herbal drug to represent a new source of antimicrobial and anti-inflammatory agent.
\end{abstract}

Key words: Scutia myrtina; Anti-inflammatory; Experimental animal; Antimicrobial activity

\section{INTRODUCTION}

Scutia myrtina Burm. F. (Rhamnaceae) is widely available in South India, especially in Kolli Hills, Tamilnadu. It is commonly known as Chimat (Hindi), a prickly shrub found through out the hotter parts of India, East Africa, Kenya, Tanzania, and South Africa. The aerial part of the plant was used for stomach problems, salpingitis. The root and leaves of the plant traditionally used as an antihelmintic (Kokwaro, 1976). The alcohol extract

*Correspondence: R Sambath Kumar, Department of Pharmaceutics and Pharmaceutical Chemistry, Natural Product Research Laboratory, J. K. K. Nataraja College of Pharmacy, Komarapalayam 638 183, Namakkal, Tamilnadu, India. E-mail: sambathju2002@yahoo.co.in of the aerial part of the plant posses' antiviral activity (Dhar et al., 1968). The root bark of Scutia myrtina is used for fever and also the infusion of the plant is used to treat malaria. An alkaloid nitidine with potent antimalarial activity has been isolated from a Kenyan herbal remedy (Gakunju et al., 1995). In eastern Tanzania the root of this plant is used for the treatment of bilharzias, intestinal worms and fever (Chhabra et al., 1982). The leaves and root bark of the Scutia myrtina decoction is used for gonorrhea, bilharzias, and intestinal worms in Tanzania (Hedberg et al., 1983).

Inflammation is a pathophysiological response of living tissues to injuries that leads to the local accumulation of plasmatic fluid and blood cells. Although it is a defense mechanism, the complex 
events and mediators involved in the inflammatory reaction can induce, maintain or aggravate many diseases. Formaldehyde, dextran, carrageenan, histamine and other inflammagen induced inflammation models are frequently used in screening for the anti-inflammatory activity of new compounds, whereas implantation of foreign body under the skin is often used to investigate the effects of drugs on the proliferative phase of the chronic inflammation model (Suleyman et al., 1991).

However, there are no reports on the antiinflammatory and antimicrobial activity of Scutia myrtina. Based on the previous literature the present work deals with acute and chronic model of antiinflammatory action by using experimental animal models and antimicrobial activity against selected bacterial and fungal strains.

\section{MATERIALS AND METHODS}

\section{Plant material and extraction}

The plant Scutia myrtina Burm. F. was collected in the month of December 2006 from the Kolli Hills, Tamilnadu, India. The plant material was taxonomically identified by the Botanical Survey of India, Coimbatore, Tamilnadu, India and the voucher specimen RRI/BNG/SMP-Prog/945 was retained in our laboratory for future reference. The entire plant of Scutia myrtina was dried under shade and then powdered with a mechanical grinder. The powder was passed through sieve number 40 and retained in sieve number 60 and stored in an airtight container for further use. The dried powder material of the plant $(500 \mathrm{~g})$ was defatted with petroleum ether $\left(60-80^{\circ} \mathrm{C}\right)$ for $48 \mathrm{~h}$ in soxhlet apparatus (yield $2.75 \% \mathrm{w} / \mathrm{w}$ ). The defatted plant material thus obtained was further extracted with ethanol for $72 \mathrm{~h}$ in the soxhlet. The solvent was removed by distillation under reduced pressure and the resulting semisolid mass was vacuum dried using rotatory flash evaporator to yield $(7.45 \% \mathrm{w} / \mathrm{w})$ a solid residue (ethanol extract).

\section{Anti-inflammatory activity Test compounds}

The petroleum ether and ethanol extract of Scutia myrtina were suspended in aqueous propylene glycol $(10 \%)$ at definite concentrations for per oral administration in rats.

\section{Animals}

Albino Wister rats of either sex $(180$ - $200 \mathrm{~g})$ were used for the present study. They were maintained under standard environmental conditions and were fed with standard pellet diet and water ad libitum.

\section{Chemicals and drugs used}

Carrageenan (S.D. Fine chemicals limited, Bombay), histamine (Sigma USA), and standard drug indomethacin (Recon, Bangalore).

\section{Anti-inflammatory models \\ Carrageenan induced rat paw oedema}

The rats were divided into 6 group $(n=6)$. Acute inflammation was induced by the sub plantar administration of $0.1 \mathrm{ml}$ of $1 \%$ suspension of carrageenan in right hind paw of rats. The $1^{\text {st }}$ group received normal saline (control), the $2^{\text {nd }}$ group received indomethacin as standard $(10 \mathrm{mg} / \mathrm{kg}$ body weight), and the $3^{\text {rd }}$ and $4^{\text {th }}$ groups received petroleum ether extract at the dose of 200 and 400 $\mathrm{mg} / \mathrm{kg}$ body weight respectively. The $5^{\text {th }}$ and $6^{\text {th }}$ groups received ethanol extract at the dose of 200 and $400 \mathrm{mg} / \mathrm{kg}$ body weight respectively. The paw volume was measured with a plethysmometer at time interval of $0,1,2$, and $3 \mathrm{~h}$ after carrageenan injection (Winter and Poster, 1957). Results were expressed as percentage inhibition of inflammation in the treated groups compared to control groups.

\section{Mediator induced inflammation}

The anti-inflammatory activity of petroleum ether and ethanol extract of this plant was measured with phlogistic agents (histamine) which acts as mediator of inflammation. The paw oedema was 
induced in rats by sub plantar injection of freshly prepared histamine $(1 \mathrm{mg} / \mathrm{kg})$. The paw oedema was measured as mentioned earlier (Winter and Poster, 1957).

\section{Cotton pellet induced granuloma}

The rats were divided into 6 groups $(n=6)$. The rats were anaesthetized and $10 \mathrm{mg}$ of sterile cotton pellets were inserted, one in each axilla. The both extracts of this plant at the dose of 200 and $400 \mathrm{mg} / \mathrm{kg}$ body weight, indomethacin (10 $\mathrm{mg} / \mathrm{kg}$ body weight) and the control vehicle were administered orally for 7 consecutive days from the day of cotton pellet implantation. The animals were anaesthetized on $8^{\text {th }}$ day and cotton pellet were removed surgically. The pellets were incubated at $37^{\circ} \mathrm{C}$ for $24 \mathrm{~h}$ and dried at $60^{\circ} \mathrm{C}$ to constant weight. Increment in the dry weight of pellets was taken as measure of granuloma formation (Winter $e t$ al., 1962).

\section{Antimicrobial activity \\ Microorganisms used}

Six strains of bacteria used were Bacillus subtilis (MTCC 736), Staphylococcus aureus (MTCC 740), Salmonella typhimurium (MTCC 98), Pseudomonas aeruginosa, Streptococcus pneumoniae (MTCC 109) and Escherichia coli (MTCC 443). These standard strains were obtained from Microbial Type Culture Collection and Gene Bank (MTCC); Institute of Microbial Technology, Chandigarh, India. The stock culture was maintained on nutrient agar medium at $4{ }^{\circ} \mathrm{C}$. Four fungal pathogens namely Candida albicans, Cryptococcus neoformans, Aspergillus flavus and Aspergillus fumigatus were isolated and obtained from National Collection of Industrial Microorganisms Pune. The stock culture was maintained in Sabouraud dextrose agar medium at $4{ }^{\circ} \mathrm{C}$.

In vitro antibacterial activity was determined by using nutrient agar and nutrient broth. In vitro antifungal activity was determined by using Sabouraud dextrose agar, yeast nitrogen base (for yeasts) and Sabouraud dextrose broth (for mycelial fungi) and they are obtained from Himedia Ltd., Mumbai.

\section{Preparation of inocula}

Twenty four hours old culture of selected bacterial/ yeast was mixed with physiological saline and the turbidity was corrected by adding sterile physiological saline until a Mac Farland turbidity standard of $0.5\left(10^{6}\right.$ colony forming units (CFU) per $\left.\mathrm{ml}\right)$. The isolates were subcultured on nutrient agar and Sabouraud dextrose agar and incubated at $37^{\circ} \mathrm{C}$ for 7-14 days. The growth was scraped aseptically, crushed and macerated thoroughly in sterile distilled water and the bacterial and fungal suspension was standardized spectrophotometrically to an absorbance of 0.600 at $450 \mathrm{~nm}$.

\section{Antibacterial and antifungal assay}

The agar diffusion method was followed for antibacterial and antifungal susceptibility test. Petri plates were prepared by pouring $10 \mathrm{ml}$ of nutrient agar for bacteria and Sabouraud dextrose agar for fungi and allowed to solidified. Plates were dried and $0.1 \mathrm{ml}$ of standardized inoculum suspension was poured and uniformly spread. The excess inoculum was drained and the inoculum was allowed to dry for $5 \mathrm{~min}$. The standard drug Ofloxacin $5 \mu \mathrm{g} / \mathrm{ml}$ (Bacteria), Miconazol $40 \mu \mathrm{g} / \mathrm{ml}$ (Fungi) and extracts such as PESM and MESM at the concentration of 100, 500 and $1000 \mu \mathrm{g} / \mathrm{ml}$ were incorporated in the cavity and the plates were incubated in BOD incubators at $37^{\circ} \mathrm{C}$ for $24 \mathrm{~h}$ (bacteria), $28^{\circ} \mathrm{C}$ for $48 \mathrm{~h}$ (yeast) and $28^{\circ} \mathrm{C}$ for 72 $96 \mathrm{~h}$ (mycelia fungi). The inhibition zone was measured. Each assay was repeated thrice.

\section{Minimum inhibitory concentration (MIC)}

Minimum inhibitory concentration of the plant extracts were tested by the two folds serial dilution method. The test extracts were dissolved in 5\% DMSO to obtain $1000 \mu \mathrm{g} / \mathrm{ml}$ stock solution. $0.5 \mathrm{ml}$ of stock solution was incorporated into $0.5 \mathrm{ml}$ of 
nutrient agar for bacteria, yeast nitrogen base for yeasts and Sabouraud dextrose broth for mycelial fungi to get a concentration of $500 \mu \mathrm{g} / \mathrm{ml}$ and serially double diluted to achieve 250, 125, 62.5 and $31.25 \mu \mathrm{g} / \mathrm{ml}$, respectively. $50 \mu \mathrm{l}$ of standardized suspension of the test organism was transferred on to each tube. The control tube contained only organisms and not the plant extract. The culture tubes were incubated in BOD incubators at $37^{\circ} \mathrm{C}$ for $24 \mathrm{~h}$ (bacteria), $28^{\circ} \mathrm{C}$ for $48 \mathrm{~h}$ (yeast) and $28^{\circ} \mathrm{C}$ for $72-96 \mathrm{~h}$ (mycelial fungi). The lowest concentrations, which did not show any growth of tested organism after macroscopic evaluation was determined as MIC.

\section{Statistical analysis}

The experimental results were expressed as the mean \pm S.E.M. and the data were assessed by student's $t$-test. $P$ value of $<0.05$ was considered as statistically significant.

\section{RESULTS AND DISCUSSION}

\section{Anti-inflammatory Studies}

The anti-inflammatory potential of petroleum ether and ethanol extract of Scutia myrtina (200 and 400 $\mathrm{mg} / \mathrm{kg}$ body weight) against experimental animal model exhibited significant anti-inflammatory activity and the results of extracts and indomethacin on the inflammation induced by carrageenan, histamine and cotton pellet induced granuloma are summarized in Table 1, 2 and 3.

As shown in Table 1, the petroleum ether and ethanol extract of Scutia myrtina showed maximum inhibition of $50.6 \%$ and $43.7 \%$ respectively at the dose of $400 \mathrm{mg} / \mathrm{kg}$ after $3 \mathrm{~h}$ of treatment in

Table 1. Effect of the petroleum ether (PESM) and ethanol extract (EESM) of Scutia myrtina on carragennaninduced pedal oedema in rats

\begin{tabular}{cccccccc}
\hline \multirow{2}{*}{ Treatment } & Dose & \multicolumn{3}{c}{ Paw volume $(\mathrm{ml})$} & \multicolumn{3}{c}{ Percentage of inhibition } \\
\cline { 2 - 8 } & $(\mathrm{mg} / \mathrm{kg})$ & after $1 \mathrm{~h}$ & after $2 \mathrm{~h}$ & After $3 \mathrm{~h}$ & $1 \mathrm{~h}$ & $2 \mathrm{~h}$ & $3 \mathrm{~h}$ \\
\hline Carragennan & $(0.1 \mathrm{ml}$ of $1 \% \mathrm{w} / \mathrm{v}, \mathrm{car}-$ & $0.82 \pm 0.04$ & $0.85 \pm 0.06$ & $0.87 \pm 0.08$ & - & - & - \\
control & $\begin{aligned} \text { ragennan in saline) } \\
\text { Indomethacin }\end{aligned}$ & & & & & & \\
PESM & 10 & $0.31 \pm 0.02^{*}$ & $0.28 \pm 0.01^{*}$ & $0.24 \pm 0.01^{* *}$ & 62.15 & 67.05 & 72.41 \\
PESM & 200 & $0.59 \pm 0.03^{* *}$ & $0.54 \pm 0.02^{*}$ & $0.48 \pm 0.02^{*}$ & 28.04 & 36.47 & 44.76 \\
EESM & 400 & $0.53 \pm 0.03^{* *}$ & $0.48 \pm 0.03^{* *}$ & $0.43 \pm 0.02^{* *}$ & 35.36 & 43.52 & 50.57 \\
EESM & 200 & $0.62 \pm 0.04^{*}$ & $0.59 \pm 0.03^{*}$ & $0.54 \pm 0.03^{*}$ & 24.39 & 30.58 & 37.93 \\
\hline
\end{tabular}

Values are mean \pm S.E.M. $(n=6)$

Experimental groups were compared with control ${ }^{*} p<0.01,{ }^{* *} p<0.05$.

Table 2. Effect of the PESM and EESM of Scutia myrtina on histamine-induced pedal oedema in rats

\begin{tabular}{|c|c|c|c|c|c|c|c|}
\hline \multirow{2}{*}{ Treatment } & \multirow{2}{*}{$\begin{array}{c}\text { Dose } \\
(\mathrm{mg} / \mathrm{kg})\end{array}$} & \multicolumn{3}{|c|}{ Paw volume (ml) } & \multicolumn{3}{|c|}{ Percentage of inhibition } \\
\hline & & after $1 \mathrm{~h}$ & after $2 \mathrm{~h}$ & after $3 \mathrm{~h}$ & in $1 \mathrm{~h}$ & in $2 \mathrm{~h}$ & in $3 \mathrm{~h}$ \\
\hline Histamine control & $\begin{array}{l}(0.1 \mathrm{ml} \text { of } 1 \% \mathrm{w} / \mathrm{v} \text {. } \\
\text { Histamine in saline })\end{array}$ & $0.81 \pm 0.07$ & $0.83 \pm 0.08$ & $0.86 \pm 0.05$ & - & - & - \\
\hline Indomethacin & 10 & $0.36 \pm 0.01^{*}$ & $0.30 \pm 0.01^{*}$ & $0.24 \pm 0.02^{*}$ & 55.55 & 63.85 & 72.09 \\
\hline PESM & 200 & $0.61 \pm 0.03^{* *}$ & $0.55 \pm 0.02^{* *}$ & $0.48 \pm 0.03^{* * *}$ & 24.69 & 33.73 & 44.18 \\
\hline PESM & 400 & $0.56 \pm 0.03^{* *}$ & $0.49 \pm 0.03^{* *}$ & $0.41 \pm 0.02^{* * *}$ & 30.86 & 40.96 & 52.32 \\
\hline EESM & 200 & $0.66 \pm 0.04^{*}$ & $0.60 \pm 0.03^{*}$ & $0.53 \pm 0.03^{*}$ & 18.52 & 27.71 & 38.37 \\
\hline EESM & 400 & $0.63 \pm 0.03^{* *}$ & $0.57 \pm 0.03^{*}$ & $0.48 \pm 0.02^{*}$ & 22.22 & 31.33 & 44.18 \\
\hline
\end{tabular}

Values are mean \pm S.E.M. $(n=6)$.

Experimental groups were compared with control ${ }^{*} p<0.01,{ }^{* *} p<0.05$ 
Table 3. Effect of the PESM and EESM of Scutia myrtina on cotton-pellets induced granuloma in rats

\begin{tabular}{cccc}
\hline Treatment & Dose $(\mathrm{mg} / \mathrm{kg})$ & Weight of cotton pellet $(\mathrm{mg})$ & Percentage of inhibition \\
\hline Control & - & $46.31 \pm 2.34$ & - \\
Indomethacin & 10 & $20.12 \pm 1.42^{*}$ & 56.60 \\
PESM & 100 & $27.23 \pm 1.60^{*}$ & 41.34 \\
PESM & 200 & $22.31 \pm 1.04^{*}$ & 51.80 \\
EESM & 100 & $28.13 \pm 1.18^{*}$ & 39.32 \\
EESM & 200 & $23.24 \pm 1.54^{*}$ & 49.91 \\
\hline
\end{tabular}

Values are mean \pm S.E.M. $(n=6)$.

Experimental groups were compared with control ${ }^{*} p<0.05$.

carrageenan induced paw oedema whereas the standard drug (indomethacin $10 \mathrm{mg} / \mathrm{kg}$ ) showed $72.4 \%$ of inhibition. The petroleum ether and ethanol extract of Scutia myrtina showed 50.6\% and $43.7 \%$ of inhibition respectively at the dose of $400 \mathrm{mg} / \mathrm{kg}$ whereas, indomethacin showed $72.09 \%$ of inhibition in histamine induced paw oedema (Table 2). In the chronic model (cotton pellet induced granuloma), the petroleum ether and ethanol extract of Scutia myrtina ( $200 \mathrm{mg} / \mathrm{kg}$ body weight) and indomethacin showed decreased formation of granuloma tissue at $51.8 \%, 49.9 \%$ and $56.6 \%$, respectively (Table 3).

The extracts of Scutia myrtina were evaluated for its anti-inflammatory activity in acute and chronic models. A significant $(P<0.05)$ anti-inflammatory activity was observed for petroleum ether and ethanol extract of Scutia myrtina in carrageenan, histamine induced oedema and cotton pellet-induced granuloma models.

Carrageenan-induced rat paw oedema has been widely used as an inflammation model to investigate the anti-inflammatory effect of drug (El-Shenawy et al., 2002). There are two phases of carrageenan induced inflammatory reaction early or first phase and later or second phase. It has been proposed that early phase results from histamine, serotonin and bradykinin liberation while late phase is associated with the release of prostaglandins (Ogonowski et al, 1997). In carrageenan induced paw oedema, the petroleum ether and ethanol extract of Scutia myrtina showed maximum inhibition of $50.6 \%$ and $43.7 \%$ at the dose of $400 \mathrm{mg} / \mathrm{kg}$ after $3 \mathrm{~h}$ of drug treatment.

Histamine is one of the important inflammatory mediator and is a potent vasodilator and has been reported to enhance the vascular permeability (Cuman et al, 2001). This study showed that all the doses of petroleum ether and ethanol extract effectively suppressed the oedema produced by the histamine, which indicates that the extracts exhibit its anti-inflammatory activity by means of either inhibiting the synthesis, release or action of inflammatory mediators viz. histamine, serotonin and prostaglandin might be involved in inflammation. From these results, it is suggested that antioedematogenic effects of the petroleum ether and ethanol extract on carrageenan and histamine induced oedema may be related to inhibition of inflammation mediator formation.

Chronic inflammation is a reaction arising when the acute response is insufficient to eliminate proinflammatory agents. Chronic inflammation includes a proliferation of fibroblasts and the infiltration of neutrophils and exudation (Dunne, 1990). Chronic inflammation occurs by means of the development of proliferative cells. These cells can either spread or form granulomas (Recio et al., 1995). Efficacy of anti-inflammatory agents in chronic inflammatory states is indicated by their ability to inhibit the increase in the number of fibroblasts and synthesis of collagen and mucopolysaccharides during granuloma tissue formation (Plummer et al., 1996). The petroleum 
Table 4. Antimicrobial activities of PESM and EESM extracts of Scutia myrtina, Ofloxacin and Miconazole nitrate on selected bacterial and fungal strains

\begin{tabular}{|c|c|c|c|c|c|c|c|c|}
\hline \multirow{3}{*}{ Microorganism } & \multicolumn{8}{|c|}{ Diameter of inhibition zone $(\mathrm{mm})$} \\
\hline & \multicolumn{3}{|c|}{ PESM $(\mu \mathrm{g} / \mathrm{ml})$} & \multicolumn{3}{|c|}{$\operatorname{MESM}(\mu \mathrm{g} / \mathrm{ml})$} & \multicolumn{2}{|c|}{ Standards $(\mu \mathrm{g} / \mathrm{ml})$} \\
\hline & 100 & 500 & 1000 & 100 & 500 & 1000 & (Ofl) 5 & (Mic) 40 \\
\hline Pseudomonas aeruginosa & 12 & 18 & 24 & 8 & 12 & 15 & 24 & \\
\hline Escherichia coli & 11 & 15 & 20 & 9 & 9 & 11 & 26 & \\
\hline Salmonella typhi & 13 & 19 & 24 & 10 & 13 & 16 & 24 & \\
\hline Staphylococcus aureus & 8 & 13 & 18 & 7 & 8 & 10 & 14 & \\
\hline Streptococcus pneumoniae & 8 & 14 & 19 & 8 & 9 & 11 & 22 & \\
\hline Bacillus subtilis & 9 & 15 & 20 & 7 & 9 & 11 & 19 & \\
\hline Candida albicans & 8 & 12 & 16 & 7 & 9 & 13 & & 21 \\
\hline Aspergillus fumigatus. & 7 & 9 & 14 & - & 7 & 10 & & 19 \\
\hline Aspergillus flavus & - & 8 & 12 & - & 7 & 10 & & 19 \\
\hline Cryptococcus neoformans & 7 & 9 & 15 & 7 & 8 & 12 & & 22 \\
\hline
\end{tabular}

Ofl: Ofloxacin ( $5 \mu \mathrm{g} / \mathrm{ml} /$ disc); Mic: Miconazole $(40 \mu \mathrm{g} / \mathrm{ml} /$ disc), (-): in active

The results are the mean values of triplicate tests repeated three times after $24-72 \mathrm{~h}$ of inhibition at $37^{\circ} \mathrm{C}$.

ether and ethanol extract of Scutia myrtina showed significant $(p<0.05)$ anti-inflammatory activity in cotton pellet induced granuloma and thus found to be an effective in chronic inflammatory condition.

Based on the results of the present study it can be concluded that petroleum ether and ethanol extract of Scutia myrtina is a potential antiinflammatory agent, and act in a dose dependent manner.

\section{Antimicrobial studies}

The antimicrobial activities of extracts of Scutia myrtina are summarized on Table 4 . The result showed that the petroleum ether and ethanol extract possessed broad spectrum activity against both bacterial and fungal organism. A total of 10 microorganisms (6 bacterial and 4 fungal organisms) were selected in the present study, both the extracts were tested against bacterial organisms such as Pseudomonas aeruginosa, Escherichia coli, Salmonella typhi, Staphylococcus aureus, Streptococcus pneumoniae, Bacillus subtilis and fungal organism like Candida albicans, Aspergillus fumigatus, Aspergillus flavus, Cryptococcus neoformans by agar diffusion method.
Results were obtained by measuring the zone of inhibition diameter in $\mathrm{mm}$. The petroleum ether extract showed more activity against both bacterial and fungal organism when compared with that of the ethanol extract. The mean zones of inhibition obtained by petroleum ether extract were between $7-24 \mathrm{~mm}$ at the concentration of 100, 500 and $1000 \mu \mathrm{g} / \mathrm{ml}$. The petroleum ether extract was the most active against pseudomonas aeruginosa, Escherichia coli and Salmonella typhi and also active against Candida albicans. The zone of diameter (in $\mathrm{mm}$ ) against fungal organism tested was $8-16 \mathrm{~mm}$ at the concentration of 100,500 , $1000 \mu \mathrm{g} / \mathrm{ml}$ of the petroleum ether extract.

Ethanol extract at the concentration of 100, 500, $1000 \mathrm{mg} / \mathrm{ml}$ were tested against bacterial and fungal organisms. The mean zones of inhibition of the extract against different test organisms were found between 7 and $16 \mathrm{~mm}$. The ethanol extract was the most active against Pseudomonas aeruginosa, Salmonella typhi and Candida albicans. The antibacterial and antifungal activities of petroleum ether and ethanol extracts against the bacterial and fungal organism were compared with the standard drug ofloxacin $(5 \mu \mathrm{g} / \mathrm{ml})$ for antibacterial and miconazole 
Table 5. Minimum Inhibitory Concentration (MIC) of petroleum ether and ethanol extracts of Scutia myrtina on selected bacterial and fungal strains

\begin{tabular}{clcc}
\hline S. No & Microorganisms & MIC of petroleum ether extract $(\mu \mathrm{g} / \mathrm{ml})$ & MIC of ethanol extracts $(\mu \mathrm{g} / \mathrm{ml})$ \\
\hline 1. & Pseudomonas aeruginosa & 125 & 250 \\
2. & Escherichia coli & 125 & 250 \\
3. & Salmonella typi & 500 & 500 \\
4. & Staphylococcus aureus & 500 & 500 \\
5. & Candida albicans & 250 & 500 \\
6. & Aspergillus fumigatus. & 500 & 1000 \\
\hline
\end{tabular}

(40 $\mu \mathrm{g} / \mathrm{ml})$ for anti-fungal activity.

The MIC of petroleum ether and ethanol extracts of Scutia myrtina against selected bacterial and fungal organisms were summarized in Table 5. The MIC of extracts was performed against selected bacterial and fungal organisms at the concentration range between 31.25 and $1000 \mu \mathrm{g} / \mathrm{ml}$ by two fold serial dilution method. The MIC values of $125-500 \mu \mathrm{g} / \mathrm{ml}$ were obtained for the petroleum extract against bacterial organism, while a range of $250-500 \mu \mathrm{g} / \mathrm{ml}$ was recorded against the fungal organism. On the other hand the MIC value obtained by antimicrobial assay using ethanol extract were $250-500 \mu \mathrm{g} / \mathrm{ml}$ against bacterial organism, while the values record in antifungal assay were $500-1000 \mu \mathrm{g} / \mathrm{ml}$.

\section{CONCLUSION}

Based on the present study it can be concluded that the petroleum ether and ethanol extracts of Scutia myrtina showed significant anti-inflammatory and antimicrobial activities. The isolation of active constituent responsible for above mentioned activities are under progress in our laboratory and the mechanism of action elucidation too.

\section{ACKNOWLEDGEMENT}

Authors are thankful to Mrs. N. Sendamaraai, Secretary \& Correspondent, J.K.K. Nataraja Educational Institution, Komarapalayam, Tamilnadu, India, for provided the abound facilities.

\section{REFERENCES}

Chhabra SC, Mahunnah RLA, Mshiu EN. (1991) Plants used in Traditional Medicine in Eastern Tanzania. V. Angiosperms (Passifloraceae to Sapindaceae). J. Ethnopharmacol. 7, 143-157.

Cuman, RKN, Bersani-Amadio CA, Fortes ZB. (2001) Influence of type 2 diabetes on the inflammatory response in rats. Inflam. Res. 50, 460-465.

Dunne MW. Pathophysiology: Concepta of altered Health States with Contributors, In: Porth CM, Lippincott eds. Philadlphia, pp. 165-176.

Dhar ML, Dhar MM, Dhawan BN, Mehrotra BN, Ray C. (1968) Screening of Indian plants for biological activity Indian J. Exp. Biol. 6, 232-247.

Hedberg I, Hedberg O, Mashigeni KE, Mshiu, EN, Samuelsson G, (1983) Inventory of plants usedin traditional medicine in Tanzania, part III Plants the families Papilionaceae-Vitaceae. J. Ethnopharmacol. 9, 237-260.

El-shenawy SM, Abdel-salam OM, Baiuomy AR, El-batran S, Arbid MS (2002) Studies on the antiinflammatory and anti-nociceptive effects of melatonin in the rat. J. Pharmacol. 46, 235-243.

Gakunju DMN, Mberu EK, Dossaji SF, Gray AI, Waigh RD, Waterman PG, Watkins WM. (1995) Potent antimalarial activity of the Alkaloid Nitidine, Isolated from a Kenyan herbal remedy. Antimicrob. Agent's Chimother. 39, 2606-2609.

Kaij-A-Kamb M, Amoros M, Girre L. (1992) Search for new antiviral agents of plant origin. Pharma. Acta. Helv. 67, 130-147.

Kokwaro JO. (1976) Medicinal plants of East Africa. East Africa literature bureau, Nairobi. 
Litchfield JT, Wilcoxon F. (1949) A simplified method of evaluating dose effect experiments. J. Pharmacol. Exp. Ther. 96, 99-133.

Ogonowski AA, May WS, Moor AB, Barret LT, Bryant CL, Pollock SH. (1997) Anti-inflammatory and analgesic activity of an inhibitor of neuropeptide amidation. J. Pharm. Exp. Ther. 280, 846-853.

Plummer JL, Cmielewski PL, Gourly GK, Owen H, Cousins M. (1996) Assessment of antinociceptive drug effects in the presence of impaired motor performance. J. Pharmacol. Meth. 26, 79-84.

Suleyman H, Buyukokuroglu ME. (2001) The effects of newly synthesized pyrazole derivatives on formaldehyde, carragennan and dextran-induced acute paw oedema in rats. Biol. Pharm. Bull. 24, 1133-1136.

Suleyman H, Demirezer LO, Kuruuzum A, Banoglu
ZN, Gocer F, Ozbakir G, Gepdireman A. (1991) Anti-inflammatory effect of the aqueous extract from Rumex patientia L. roots, J. Ethnopharmacol. 65, 141-148.

Recio MC, Giner GM, Manez S, Ros JL. (1995) Structural requirements for the anti-inflammatory activity of natural terpenoids. Planta. Med. 6, 182-185.

Winter CA, Poster CC. (1957) Effect of alteration in side chain up on anti-inflammatory and liver glycogen activities in hydrocortisone ester. J. Am. Pharmacol. Soc. 46, 515-519.

Winter CA, Risely EA, Nuss GW. (1962) Carrageenan induced oedema in hind paw of the rat as assays for anti-inflammatory drugs. Exp. Biol. Med. 111, 544-547. 